\title{
An Overview of New Labour Law in Rwanda
}

\author{
Francis Mwangi Waweru \\ School of Business and Economics, Mount Kenya University Rwanda, P.o Box 5826 Kigali Rwanda
}

\begin{abstract}
Labour law is fundamental in creating and maintaining employee relations, high productivity and a conducive work environment. Rwanda repealed the labour law in 2018 to align it to international best practice. This paper gives an overview of the Rwanda new labour law and evaluates its relevance in employee relations. There is need to disseminate the requirements of the new law to human resource professionals and practitioners in Rwanda to enhance compliance and avoid unnecessary labour disputes and costs. Rwanda has one of the most tranquil industrial relations climates in the East African region, and its pragmatic and progressive labour law is a contributing factor worth exploring. Conclusions and recommendations for human resource management practice are given.
\end{abstract}

Keywords: Rwanda new labour law, employee relations

DOI: $10.7176 /$ RHSS/9-18-02

Publication date:September $30^{\text {th }} 2019$

\section{Introduction}

Knowledge of the Labour Law makes work for HR professionals easier, consistent, predictable and accurate. It improves the work environment by ensuring that the parties to the employment relationship treat each other with respect, dignity, fairness and justice. Labour disputes are minimized and when they occur are resolved amicably within well-defined guidelines. Labour dispute is any misunderstanding between employees and employers concerning pay, conditions or tenure of employment (Shen, 2008). The new labour law distinguishes between collective and individual labour disputes. Collective labour disputes refer to 'disagreements between one or more employers on the one hand, and some or all employees on the other hand, which arises from collective convention or working conditions' (Art. 3 clause 10, p.23). An individual labour dispute is defined as 'a disagreement between one or more employees and an employer as a result of a breach of the employment contract concluded between them'(Art 3 clause 11, p.24).

Violation of employees' rights: delayed payment, failure to pay, workplace accidents; job losses, mismanagement are common sources of labour disputes (Shen, 2008). The Global Nonviolent Action Data Base (2011) reported a strike of 500 workers of a manufacturing firm in 2011 out of sympathy for 30 unfairly dismissed colleagues, poor working conditions, low pay, lack of annual leave, and non-paid overtime. Lack of channel for grievances escalated the dispute. According to ILO (2017) statistics, $18.9 \%$ of employees in Rwanda worked more than 48 hours per week. That is a potential source of dispute especially if the employees are not compensated for extra hours worked.

Labour Law No. 66/2018 of 30/08/2018 Law Regulating Labour in Rwanda repealed and replaced Law No. 13/2009 of 27/05/2009 Regulating Labour in Rwanda. The new labour law took effect when it was published in the Official Gazette number Special of 06/09/2018. The law regulates all employment matters for employees in the private sector, contractual staff in public sector, interns, apprenticeships, and self-employed persons but only in regard to occupational health and safety (Art 2). As such, the labour law does not apply to other employees in public service unless otherwise stated by the general statutes regulating public sector employees.

Why was the labour law repealed? The new law was enacted to align it to International Labour Orgnization (ILO) conventions which Rwanda has ratified and also to address concerns and gaps which stakeholders had noted in the repealed law, for example where it tended to disadvantage one party to the employment contract and where sanctions for labour offenses were not stipulated.

\section{Rights and obligations of employer and employee}

The labour law is the framework which spells out and protects the fundamental and reciprocal rights and obligations of employees and employers. Rights and obligations of an employer and employee under the Rwandan labour law are summarized in Table 1. 
Table 1: Rights and obligations of employer and employee (Compiled by the author)

\begin{tabular}{|c|c|c|}
\hline & Employer & Employee \\
\hline Rights & $\begin{array}{ll}\text { - } & \text { Recruit } \\
\text { - } & \text { Give instructions related to the work } \\
\text { - } & \text { Evaluate employee } \\
\text { - } & \text { Transfer } \\
\text { - } & \text { Promote } \\
\text { - } & \text { Discipline } \\
\text { - } & \text { Terminate contract } \\
\text { - } & \text { Modify, extend or cease activities } \\
& (\text { Art 38) }\end{array}$ & $\begin{array}{l}\text { - To work in safe and } \\
\text { healthy conditions } \\
\text { - } \text { Receive equal salary for } \\
\text { work of equal value } \\
\text { - } \text { Be provided leave } \\
\text { according to the Law } \\
\text { - Join a trade union of } \\
\text { his/her choice } \\
\text { - Be trained by employer } \\
\text { - To receive information } \\
\text { related to the work } \\
\text { (Art 40) }\end{array}$ \\
\hline Obligations & $\begin{array}{l}\text { - } \quad \text { Provide employment contract/copy } \\
\text { - } \quad \text { Provide agreed work at agreed time and place } \\
\text { - } \quad \text { Supervise employee } \\
\text { - } \quad \text { Ensure safety and health conditions } \\
\text { - } \quad \text { Pay agreed salary on time } \\
\text { - } \text { employees, environment } \\
\text { - } \quad \text { To discuss with employees matters related to work } \\
\text { - } \quad \text { Provide professional training } \\
\text { - } \text { Provide working equipment } \\
\text { Notify to labour inspector of work-related accident } \\
\text { /death } \\
\text { (Art 39) }\end{array}$ & $\begin{array}{l}\text { - } \text { Personally do the work } \\
\text { - Performance } \\
\text { - Respect employer's } \\
\text { instructions or those of } \\
\text { his/her representative } \\
\text { - Refrain from anything } \\
\text { that jeopardizes security } \\
\text { - Keep in good condition } \\
\text { assigned tools } \\
\text { - } \text { Report on time } \\
\text { Protect interests of the } \\
\text { work. } \\
\text { (Art 41) }\end{array}$ \\
\hline
\end{tabular}

The rights of one party translate into obligations of the other and the obligations of one the rights of the other.

\section{Prohibitions}

The laws of Rwanda eliminate many potential causes of grievances in the workplace by prohibiting some forms of child labour, all forms of discrimination, forced labour, and sexual harassment. Minimum age for admission of employment is 16 years except that 13 - 15 years old children can do light work under apprenticeship. Children who are 13 years old and above can be employed for light work which does not have detrimental effect on education, health and physical development or other aspects of child's interest (Art.3). What is light work and what is not will be determined by a ministerial order.

\section{Employment contracts}

There are potential sources of grievances that are addressed by having employment contracts that abide with the law (Art. 11). An employment contract can be fixed term or indefinite, written or unwritten. Unwritten contract should however not exceed 90 days. The labour law is elaborate on the minimum requirements of an employment contract as follows. Employment contract:
i. is entered under mutual consent
ii. can be entered with more than one employer if not compromising one another
iii. can be fixed term or indefinite
iv. can be written or oral (unwritten should not exceed 90 days); proof of contract can be by any means
v. can be modified in the course of implementation at the request of one party and with consent of both parties
vi. $\quad$ existing contracts remain valid when enterprise changes status.
vii. not transferrable to another employer without employee's consent
viii. can be suspended for a duration on certain grounds (legal strike/lockout, disciplinary suspension, administrative investigation, technical/economic difficulties, imprisonment/detention for not exceeding 6 months, force majeure, among others).

\subsection{Probation (Art. 13)}

Probation period is used to evaluate each other (employer and employer). Allegation of violation of employee's 
rights under probation can be a potential source of grievances. In Rwanda, probation period provided for under the law is three months which can be extended for another 3 months after evaluation of employee's performance and evaluation report has to be notified to the employee. No terminal benefits are payable to employees under probation neither is any notice period in case of termination due.

\subsection{Foreign employees}

The labour law regulates the relationship between the employer and foreign employee to preempt disputes between the parties. In regard to employment of a foreign employee (Art. 12):

i. There has to be a written contract for a foreign employee.

ii. Matters relating to requirements for a work permit for a foreign employee are dealt with according to immigration and emigration laws.

iii. A ministerial order regulates employment for foreign employees in Rwanda. Ministerial order is published in the Official Gazette of the government.

\subsection{Termination of employment contract (Art 27 and 28)}

Violation of rights during termination is a common cause of grievances and disputes in employment. A contract for employment can be terminated by 1) mutual consent of both parties. This applies for both for both fixed term and indefinite contracts. 2) Expiry of a fixed term contract. This does not ordinarily raise disputes except perhaps in regard to payment for work already done and outstanding annual leave. 3) Termination due to valid reasons.

The following provisions safeguard against unnecessary disputes:

i. The period for termination notice is 15 days (if employee had worked for less than 12 months of service) but if employee had worked for one year or longer the applicable notice period is 30 days.

ii. Termination must be in writing and legitimate reasons should be given for it. No notice necessary in case of mutual consent.

iii. Contracts of employment cannot be terminated during suspension or leave.

iv. During notice employee is entitled to one day off per week to look for work.

v. Compensation for breach of notice requirement.

vi. $\quad$ No notice given in case of termination due to gross misconduct

vii. In case of termination due to gross misconduct, employee must be notified within 48 hours of the evidence of occurrence of the gross misconduct specifying grounds for termination

viii. An order of the Minister for labour determines the list of gross misconduct

ix. Unlawful termination attracts damages payable to the aggrieved party; The damages range from $3-6$ months' salary but if the employee had worked for at least 10 years with same employer the damages are not more than 9 month salary.

x. Terminal benefits are only payable due to an employee discharged on economic, technological or sickness reasons varying with the period worked. Retirement benefits are determined in the same way. Terminal benefits are payable within working 7 days of the termination.

xi. Certificate of rendered services after expiry of contract specifying start and end date of employment and nature of employment/position. Failure to issue the document within 15 days of employee's written request or omitting any of the details attracts damages of 1 month salary payable to employee.

How disciplinary cases are handled can be reason for disagreement between employees and employers. In Rwanda disciplinary action can be progressive or not depending on the severity of the offense the employee is accused of. Hence, disciplinary sanctions depend on severity of misconduct, provisions of favorable collective conventions, internal rules of procedure and provisions of contract of employment. Sanctions include oral warning, written warning, temporary suspension up to 8 days without pay, and dismissal or termination of the employment contract (Art 42). This suspension should not be confused with suspension for administrative investigation. Suspension of employment contract can be done due to administrative investigation by employer (Art. 30) for not more than 30 days without payment but employee's salary is retained and paid later if innocence is proven. In case the offense is gross misconduct the employment contract termination should be done after conclusion of the investigation within the 30 days and be within 48 hours of getting the evidence of the misconduct.

The labour law of Rwanda protects employees dismissed due to technical or economic reasons. Right of being reinstated after being dismissed for economic or technical reasons (Art. 22) exists within 6 months without competition when he or she meets the requirements for the position to which the employer seeks to fill.

Damages for not respecting notice period are payable (Art. 25) by the party in breach of the notice requirement. Damages cannot go below 3 months' salary and not beyond 6 months' salary but if employee has worked for 10 years or more with the same employer damages cannot exceed 9 months' salary of the dismissed employee.

Damages for termination (Art 30) are payable in case of wrongful dismissal and depend on period served by 
employee. Employees who have served for less than 10 years with same employer are entitled to between 3 and 6 months' salary while those who served more than 10 years can get up to 9 months' salary in compensation. These damages also apply to officials dismissed unlawfully due to discharge of their duties (employees' representatives, trade union officials and members of occupational health and safety committees).

Terminal benefits (Art 31) are only payable for termination due to economic reasons, technological transfer or sickness for an employee having served for at least 12 consecutive months.

An employee is entitled to a certificate of service upon termination of contract. Damages for not issuing a certificate of rendered services or not correcting one as requested or omitting one of the elements it must contain (nature of work done and start and end time) is one month salary but employee is required to prove that he or she requested for it in writing.

\section{Transfer to another job or organization}

The law anticipates situations where an employee can be moved to another job or organization by the employer while the current contract is in progress. Moving an employee to another position different from the one applied for and reducing salary and benefits may disadvantage the employee and is not allowed by the law, unless employee consents to the changes. An employee can be transferred to another position different from the one employee applied for in employer's interest but without reducing employee's salary and benefits. It is prohibited to transfer an employee to another position or level of employment that leads to reduction of the salary or level without employee's consent (Art .17).

\section{Occupational health and safety}

The entire of Chapter V (Articles $77-82$ ) is dedicated to occupational health and safety. The employer is required to maintain a safe and healthy work environment. In particular, the law requires the following of the employer in regard to occupational health and safety:

- Employer to ensure safe and healthy conditions in premises at employers cost

- Occupational health and safety committee to be set up in organization

- Personal protective equipment to be provided for hazardous work - instructions and verification for use

- First-aid, firefighting and protective measures to be put in place

- Employer required to fight and prevent occupational diseases including assessment and policy among others

- Employer to declare occupational disease, accident and death to RSSB and labour inspector

The law requires that an employer should contribute to a social security body in Rwanda, otherwise the employer will be liable to compensate an injured or sick employee the extent social security would have compensated; therefore, if the employer did not contribute social security benefits for employee, in case of accident or disease the employer pays equivalent of what the social security body would have paid if employee had been registered. The employee affected by occupational disease or injury cannot be dismissed unless a doctor declares in writing that employee is unfit to resume service; alternative work should be given if fit or dismiss and pay benefits if work not available. Funeral and death allowances are payable to family of deceased employee according to an order of the Minister. In case of subcontract, the salary and social security contributions and other obligations of employer towards employees are guaranteed under the subcontract (Art 19).

\section{Working hours and leave}

Working hours are a major cause of labour disputes. The labour law in Rwanda provides for a maximum of 45 working hours per week (excludes daily and weekly rest breaks) but extra hours can be worked with agreement with employer (Art 43). Daily schedule and timetable determined by employer. Weekly rest breaks of not less than 24 hours should be provided to the employee (Art 44).

Outstanding leave entitlement feature often in employer-employee disputes especially when the contract of employment is terminated. Refusal to grant leave due can also be a source of friction in employer-employee relations. The leave entitlement of an employee under the Rwandan labour law can be summarized as follows:

i. Maternity leave (Articles 56 to 61) - a female employee who gives birth is entitled to 12 weeks of maternity leave; can include 2 weeks before delivery and extension of one month with pay in case of complications for mother or child related to the childbirth ascertained by recognized medical doctor. Certificate of delivery /certificate of probable date of delivery to be furnished before starting maternity leave issued by a recognized health facility. After the maternity leave, the employee is entitled to paid breastfeeding breaks of 1 hour per day for 12 months. After maternity leave employee should resume to same position and there should be no dismissal during maternity leave. Safe working conditions should be provided for breastfeeding or pregnant employee.

ii. Articles 46 - 50 give requirements for annual leave. Annual leave with pay of not more than 21 days 
must be provided and should not be paid with cash except as provided by Law, at the rate of 1.5 days per month of work except children below 18 but above 16 years who are entitled to 2 days per month worked. An employee is entitled to 1 day of paid leave for every 3 years of experience but maximum duration of paid annual leave remains 21 days. Official public holidays are excluded in computing annual leave. New employees enjoy leave after 12 months including probation. Annual leave that is suspended when it coincides with another leave resumes after that other leave. Expiry of right to annual leave is two years from date employee had right to leave. Annual leave schedule is drawn to accommodate leave wishes of employee and normal functioning of the organization. Annual leave request should be in writing and annual leave can be taken in two phases. Annual leave compensation indemnity is paid for outstanding annual leave when the contract expires or is terminated, even for employees who were in their first year of service.

iii. Sick leave - short term sick leave is granted to an employee for not more than 15 days upon providing a medical certificate from a recognized medical doctor that shows inability to work (Art 54). Long-term sick leave is ascertained by a committee of 3 recognized medical doctors and is granted for 3 months with pay and 3 months without pay (suspension of employment contract). The employment contract of an employee who is unable to resume work due to illness after the 3 months suspension of work may be terminated (Art 55).

iv. Circumstantial leave. This is leave with pay granted for fortunate and unfortunate events in family; modalities for it are determined by an order of the Minister in charge of labour (Art 51).

v. Authorized absences for justifiable reasons (Art 52).

vi. Official public holidays - an employee is entitled to payment during public holidays and if he/she works during public holiday then is entitled to equivalent time off duty within 30 days (Art 53) .

\section{Salary and wages}

Salary is potentially contentious zone in industrial relations but the labour law of Rwanda defines the requirements for salary as follows.

Employee is entitled to salary except where provided for by contract or law, and where no work has been performed; to be paid in currency provided by Law, in full and through bank; frequency of payment of salary (daily, weekly, fortnightly, monthly) depends on terms of contract under which employee was recruited; entitle to a detailed individual monthly payroll (payslip); no unauthorized deductions otherwise employee will be repaid with interest whose rate will be determined by National Bank of Rwanda (NBR); deductions should not exceed a half of the salary; no interest to be charged on deductions. Salary prescription is 2 years except where there is a pending matter that has been reported to employee reps or to labour inspector or to court of law

If employer issues tender to someone or organization and the subcontractor did not pay the workers the employer should retain the payment or part of it equivalent to salaries until subcontractor pays the workers. The employer will pay the employees out of the retained funds if subcontractor does not pay them (Art 23). This implies that proof will be required of the subcontractor that salaries have been paid to workers before the employer can release the retained funds. If no such proof is provided by the subcontractor within 45 days then the employer will go ahead and pay workers the salaries due to them (Art 122).

\section{Freedom of association}

The labour law guarantees right to freedom of opinion and association regarding working conditions, execution of work, and organization. These freedom includes right of employees and employers to form, join and participate in employees' or employers' associations respectively (Articles 83 and 84). These associations have to be registered under the law (Art 85) and they enjoy legal personality after publication of their Articles in the Official Gazette of the Republic of Rwanda (Art 86). Legal personality grants the associations power to file cases in courts of law, represent employees or employers, acquire property, enter into agreements with other associations. The associations have a right of entry into organizations to recruit members or hold meetings provided they have obtained consent of management of the organization. If such consent is not granted, the matter can be referred to the labour inspector of the area (Art 88). The federation representing employees and the one representing employers are the ones elected by majority of employees/employers. The federation will represent the employees/employers for three years basing on the election results and the number of registered, regularly contributing members (Articles 89 and 90).

\section{Collective agreements}

The items a collective bargaining agreement must contain are specified in Article 91. These include conditions for recruitment and termination, employees' right of joining trade union and freedom of opinion, categories of professional cadres and salary applicable to each, overtime rates, probation period, paid leave, seniority allowance, revision of the collective agreement, how disputes arising from the implementation of the agreement 
will be settled, and commencement date of the collective agreement. Collective agreements should have more favorable terms for employees but contracts of employment and internal rules will prevail if they are more favorable (Art 92).

Collective agreements are (Articles $93-97$ ):

i. negotiated in good faith meaning the parties have an obligation to cooperate and provide required information

ii. $\quad$ Are in writing and signed by both parties.

iii. Can be for a specified or unspecified duration of time

iv. Can be extended if it applies to two thirds or more of number of employees or employers representing the category of profession that is subject of extension. The extension can also be ended upon mutual agreement.

v. Can apply to all employees or employers in an area or professional categories as provided in the agreement

vi. negotiated by a committee agreed upon by both parties

Employer informs all employees about the collective agreement and the workers representatives and labour inspector of the area are also given copies of the agreement (Art 99).

\section{Dispute settlement}

Labour disputes between individual employees and their employers are to be settled amicably in the workplace by representatives of workers but if this fails then the aggrieved party should refer the dispute o the labour inspector of the area where the organization is located. If the dispute is not settled at that point then it is refrerred to either a court of law or to the national labour inspector depending on the nature and circumstances of the case (Art 102). Collective labour disputes are also notified to the labour inspector of the area where the organization is located and referred to the national labour inspector but if not settled owing to the nature of the case or conflict of interests, the dispute is referred to the minister in charge of labour for settlement (Art 103).

Claims for labour disputes should be lodged promptly otherwise according to Article 104, such a claim arising from work lapses within 2 years unless it is written or referred to workers' representatives, labour inspector or a court of law for settlement.

\section{Strikes and Lockouts}

Both employees and employers have the right to strikes and lockouts but the law contemplates that before these actions can be effected, prior notice of 4 days has to be given, other mechanisms for settlement of disputes should have been exhausted and essential services should not be affected. These amicable dispute resolution mechanisms are arbitration, conciliation and litigation. In particular, the strike or lockout should be done if 15 days have elapsed before the arbitration decision is made or conciliation resolution or court award are implemented (Art 105). The provisions that only a court can declare a strike or lockout illegal (Art 106) and that employment relationship is not affected by a strike or lockout (Art 107) cements independence of these potential courses of industrial action. Employers or their representatives and employees or their representatives must be careful not to go on an illegal strike or lockout because of the attendant negative consequences. Employees would be required to pay for damages caused by them and lose pay for period not worked while employers risk paying workers for the duration of illegal lockout, loss of right to bid for tender for 6 months, deregistration and either temporal or definite suspension of business (Art 109).

\section{Labour Organs:}

i. Director of Labour Administration heads Labour Administration organ which is responsible for formulation and monitoring of implementation of national policy and employment-related laws. Director of Labour Administration has the same powers as the Labour Inspector in regard to labour inspection (Art 112).

ii. Labour inspectorate which plays crucial roles of monitoring compliance, implementing orders, collective agreements, giving information and advice relating to labour laws and social security (Art 113).

iii. Employees' representatives and their alternates who are elected by their fellow employees. Modalities of their election and functioning are determined by an order of the minister in charge of labour (Art 114).

\section{Parties to Industrial relations in Rwanda}

Industrial relations are managed in the context of interacting and interdependent parties and environmental factors and hence form a subset of society (Omotayo \& Ome-Ogeonu, 2014). Three different actors (government, employers and employees and their representatives) have distinct roles and must work together as a system. The 
interactions result in a set of rules of which labour laws are part.

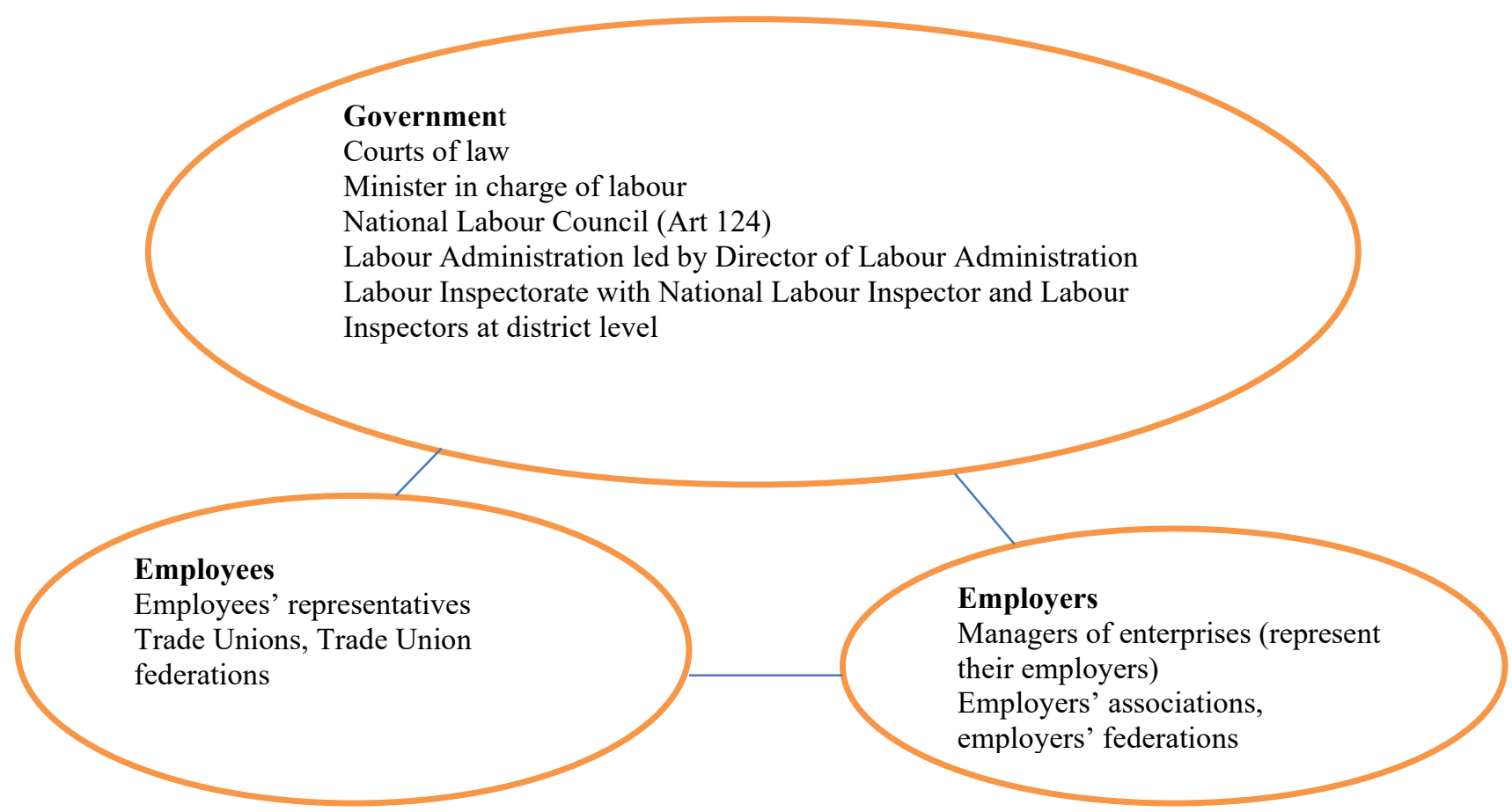

Figure 1: Parties to Industrial relations in Rwanda

Source: Adapted from Dunlop's industrial relations system theory (Omotayo. \& Ome-Ogeonu, 2014).

Private employment agencies can be formed (through a letter of authorization issued by the minister in charge of labour upon application) to provide labour market services such as recruitment, training, advisory services, information services or any other services authorized by the minister in charge of labour. An order of the minister in charge of labour determines the modalities of their establishment and functioning of these agencies (Art 115).

Organizations which are set up should inform the labour inspector of their area declaring the situation of their employees within 1 month of setting up the organization. Likewise, an organization should inform the labour inspector of the area at least 15 days before closing business or relocating to another area (Art 116).

\section{Rules of procedure}

Employer organizations should amend their internal rules and regulations to be consistent with the new labour law. This is because although the contracts of employment that came into force before this law are valid, any inconsistent clauses must be amended within 12 months from the date the law came into force (Art 123). It is a requirement that an organization that has 5 or more employees should make rules of procedure after consultation with employees' representatives) and communicate the same to employees and to labour inspector (within 30 days of commencement. The rules take effect after communication to employees (Art 100-101).

\section{Offences, administrative misconducts and their sanctions/penalties}

The new labour law in Chapter XII outlines the offences and the sanctions applicable to each. The following offences are punishable by imprisonment: prohibited child labour, illegal strikes and lockouts, and occupational health and safety violations. Most of the offences apply to employers but some are also committed by employees such as illegal strike and violations of occupational health and safety (Table 2). 
Table 2: Offences and their penalties (Compiled by the author)

\begin{tabular}{|l|l|l|l|l|}
\hline Article & Offence & \multicolumn{2}{|l|}{ Penalty if a natural person } & $\begin{array}{l}\text { Penalty if an } \\
\text { Organization }\end{array}$ \\
\hline 117 & Prohibited work for a child & $\begin{array}{l}\text { Imprisonment } \\
\text { Not less than 2 } \\
\text { years and not } \\
\text { more than 5 } \\
\text { years }\end{array}$ & $\begin{array}{l}\text { Fone } \\
\text { not less than 500,000Rwf and } \\
\text { addition to imprisonment }\end{array}$ & $\begin{array}{l}\text { Double the fine } \\
\text { for natural } \\
\text { person }\end{array}$ \\
\hline 118 & $\begin{array}{l}\text { Illegal strike or lockout } \\
\text { *Articles 108 and 109 } \\
\text { provide for other } \\
\text { consequences of an illegal } \\
\text { strike or lockout }\end{array}$ & $\begin{array}{l}\text { Not less than 6 } \\
\text { months }\end{array}$ & $\begin{array}{l}\text { Not less than 500,000Rwf and } \\
\text { not more than 5 million Rwf } \\
\text { (Both and imprisonment or one } \\
\text { of these penalties) }\end{array}$ & $\begin{array}{l}\text { Double the fine } \\
\text { for natural } \\
\text { person }\end{array}$ \\
\hline 119 & $\begin{array}{l}\text { Occupational health and } \\
\text { safety }\end{array}$ & $\begin{array}{l}\text { Not less than 6 } \\
\text { months and not } \\
\text { more than 2 } \\
\text { years }\end{array}$ & $\begin{array}{l}\text { Not less than 500,000Rwf and } \\
\text { not more than 2 million Rwf } \\
\text { (Both and imprisonment or one } \\
\text { of these penalties) }\end{array}$ & $\begin{array}{l}\text { Double the fine } \\
\text { for natural } \\
\text { person }\end{array}$ \\
\cline { 2 - 5 } & $\begin{array}{l}\text { Occupational health and } \\
\text { safety but where death has } \\
\text { occurred }\end{array}$ & $\begin{array}{l}\text { 2 years to 5 } \\
\text { years }\end{array}$ & $\begin{array}{l}\text { 2 million Rwf to 5 million Rwf } \\
\text { (Both and imprisonment or one } \\
\text { of these penalties) }\end{array}$ & $\begin{array}{l}\text { Double the fine } \\
\text { for natural } \\
\text { person }\end{array}$ \\
\hline
\end{tabular}

Refusal to allow labour inspector entry, provide information, respond to summon or implement recommendations are termed administrative misconducts in the new labour law and some fines are prescribed accordingly (Table 3 ).

Table 3: Administrative misconducts and their sanctions (Compiled by the author)

\begin{tabular}{|l|l|l|}
\hline Article & Administrative misconducts & Sanction \\
\hline 120 & $\begin{array}{l}\text { Obstructing the functioning of the labour } \\
\text { inspectorate }\end{array}$ & $\begin{array}{l}\text { Administrative fine of not less than 100,000Rwf and not } \\
\text { more than 2 million Rwf }\end{array}$ \\
\hline 121 & Cited in Articles 117,118,119 and 120 & Temporary closure of the organization \\
\hline
\end{tabular}

Obstructing the regulatory work of the labour inspector and committing any of the other offenses cited in articles 117,118 and 119 can therefore have serious consequences not just financial but can also risk suspension of operating license of an enterprise.

\section{Discussion}

The new labour law of Rwanda is progressive and embeds industrial democracy. It provides for employees' representatives and allows collective bargaining which enhances productivity. In Uganda, a study found that involvement, collective bargaining and communication had positive effects on performance of teachers (Nantege, 2017). A study conducted in Turkey targeting large firms found that improving ER led to increase in employee satisfaction and productivity, and reduced turnover (Tansel \& Gazîoğlu, 2014). Employee satisfaction was measured by satisfaction with pay, achievement, respect from supervisor and influence over job. Refusal to engage workers in dialogue, resolve grievances or address disputes can escalate conflict that can have negative impact including need for unionization. A study of a multinational car manufacturer in India found that workers who initially used non-violent means to protest degenerated into violent means when management refused to engage the workers for a joint solution and instead suspended some workers and refused to recognize their union (Mathew \& Jones, 2012). Similarly, Maree (2016) traced the evolution of labour unrest by black South Africans and concluded that many strikes turn violent (militancy) with costly consequences to both parties. A positive organizational climate is an intangible resource that can be used to gain a competitive advantage over competitors (Ali, Lei, \& Wei, 2017). Improved employee relations enhances customer care and employees support for each other (Chuang \& Liao, 2010) and was found to have a mediating effect between strategic human resource management and operational performance of banks in China (Ali, Lei, \& Wei, 2017).

The freedom of association is embedded in not only the labour law but also the constitution of the country (for instance Articles 34, 38 and 39 of the Constitution of the Republic of Rwanda of 2003 Revised in 2015). Consequently, restrictive labour legislation is one of the least significant of factors cited as impeding doing business in Rwanda (World Economic Forum, Executive Opinion Survey 2017). The labour law provides regulation of the relationship between trade unions and employers' representatives through collective bargaining and industrial action if collective bargaining fails (Blyton \& Turnbull, 1994). The labour law in Rwanda empowers workers' representatives and labour inspectors in resolving labour disputes which in a way recognizes the worldwide shift from industrial relations to employee relations; this shift is driven by decline in collectivism and trade unions, falling union membership, growth of service and knowledge based economy, mass 
retrenchment and layoffs; employee relations is largely based on agreement between a single employer and individual employee (Itika, 2011). The new labour law therefore tends to focuses on employees as the most important assets in an organization; this is also a shift towards employee relations away from industrial relations which totally relied on laws and the institutions that regulate relations in the workplace (Nikoloski, Dimitrova, Koleva, \& Kacarski, 2014). All in all, the new labour law creates room to accommodate both unitarist (encourages cooperation, consulting and mutual agreement through workers' representatives and labour inspectors) and plularist (trade unions and employers' associations/federations are allowed) approaches to industrial relations while at the same time pre-empting any need for Marxist approach by providing multiple avenues (including arbitration and conciliation) to resolve labour conflicts amicably.

Amicable resolution of labour disputes creates a peaceful atmosphere for production. Dispute resolution through workers representatives, labour inspectors, conciliation and arbitration are provided for in labour law before litigation sets in as a last resort. These mechanisms facilitate alternative ways of resolving conflicts. This peaceful settlement of labour disputes can help in improving productivity of the organization by increasing motivation and morale of the workers (Nikoloski, Dimitrova, Koleva, \& Kacarski, 2014). In a study, 50\% of employees considered two-way flow of information as very important for their performance, while 50.3\% consider involvement as very important (Gabčanová, 2011). The use of workers' representatives who are not even from trade unions is a plus in the Rwandan labour law. A study in British Isles found that coaching employees and their leaders in one-to-one conflict resolution skills was liked by employees and helped to address personal conflict, and reduced the need for management intervention hence saving them time. For some kinds of challenges e.g. bullying in the workplace, $77.4 \%$ of victims prefer to consult colleagues before direct supervisors (51.4\%) (McGrane, Wilson \& Cammock, 2005). Litigation is adversarial, involves high costs and time wastage; alternative settlement mechanisms have advantages (saves time, affordable, privacy, amicable, flexible, high decision acceptance) though they may also carry costs, not always enforceable, may lack of welltrained professionals, among others criticisms (McGrane, Wilson \& Cammock, 2005).

The new labour law of Rwanda has provided for termination due to economic or technological reasons and made the termination fair and just to both the employers and employees. In the repealed law this was a thorny matter. Economic and technological changes can necessitate layoffs and labour disputes. Implementation of market reforms in 1978 in China led to an increase in labour disputes (Shen, 2008). It is commendable that such disputes have been forestalled by the new labour law. This may also bring about an atmosphere of trust and fair treatment in line with the psychological contract which is a set of implicit needs and expectations of both the employee and the employer on what they expect to receive from each other (Guest, 2001). This approach unifies the other (unitarist, pluralist and Marxist) employee relations approaches (Itika, 2011). In case of transfers, the employer should retain the written proof of consent; the employer should inform employee reason about the changes in written form; request for the employee's consent in written form.

The new labour law provides for progressive discipline depending on the severity of the offence. Appropriate interpretation of the successive stages of disciplinary sanctions can prevent disputes. For instance, an employee suspended for 8 days is enough sanction for the misconduct and the employee should not be terminated based on the same offense. In other words, the employer should not apply more than one sanction for the same offense. It is noteworthy that an employer is not obliged to use progressive sanctions (oral warning, written reprimand, suspension, dismissal); can take higher sanction in the first instance depending on the gravity of the offense, for instance in case of gross misconduct (Art 26).

The repealed labour law 'favoured employees' but this imbalance has been rectified in the new labour law. Whereas employees are quick to seek justice when an employer is in breach of contract of employment, it is rare for employers to sue for damages if employee leaves without respecting notice terms which is quite common. In case employee absconds without giving notice it is not advisable for employer to withhold salary for period worked or work done, many employers err in doing that; if employee has not cleared with institution the employee may seek other means or laws to recover the items owed by employer using the proof of issuing those items to employee e.g. write to employee requiring submission but do not withhold the employee's salary for work done or period worked. For instance sue employee for damages. Deduction of value of owed items can be done if employee signed a document acknowledging receipt of the items and authorizing employer to deduct the value of the items from the salary if employee does not surrender the items to employer at time required or upon termination or resignation.

Termination should not be done unless the employer has a legitimate motive. To deal with burden of proof on employer, court bailiffs can be used to deliver communication to employee as last resort because it can alarm the employee and cause unnecessary panic. Instead do it in a meeting attended by employee representatives and any other witnesses and let the attendees sign the document and file the document. Employee should be made to sign a declaration that any communication sent through email is official and any changes to the email should be communicated to the employer. It is advisable that the employer should open an official email for the employee for all official communication. 


\section{Conclusions}

The new labour law of Rwanda (2018) addresses the concerns which the employers and employees had with respect to the repealed law (2009) and aligns with the requirements of International Labour Organization. It has clarified and expanded the rights as well as obligations of both employers and employees. The law delegates to the minister in charge of labour to determine certain matters such as what constitutes gross misconduct among many others. When it is applied consistently, the new law is expected to pave way for more peaceful employee and industrial relations and enhanced climate for production and investment in Rwanda than ever before.

\section{Recommendations}

Human resource practitioners and professionals should document offenses committed by employee or any actions taken in regard to that. This will facilitate fast and accurate resolution of any arising disputes with employees.

i. The new labour law has many differences with the repealed law. Although some seminars have been organized by various organizations to sensitize their members, this training should be enhanced particularly outside Kigali City to improve compliance.

ii. The employer should specify offenses in their internal rules and regulations upon which disciplinary sanctions will be based and upon which termination will be done.

iii. The labour law provides minimum standards which employers and employees should adhere to. The employers may provide more favorable terms and conditions of employment for their employees to enhance their brand as employer of choice.

\section{References}

Ali, M., Lei, S., \& Wei, X.-Y. (2017). "The mediating role of the employee relations climate in the relationship between strategic HRM and organizational performance in Chinese banks", Journal of Innovation \& Knowledge, 3(3), 115-122. https://doi.org/10.1016/j.jik.2016.12.003

Aysit Tansel, Şaziye Gazîoğlu, (2014). "Management-employee relations, firm size and job satisfaction", International Journal of Manpower, Vol. 35 Issue: 8, pp.1260-1275, https://eresources.mku.ac.ke:2079/10.1108/IJM-09-2014-0179

Chuang, C. \& Liao, H. (2010). Strategic human resource management in service context: Taking care of business by taking care of employees and customers. Personnel Psychology, 63 (2010), pp. 153-196

Fodhla McGrane, John Wilson, Tommy Cammock, (2005) "Leading employees in one-to-one dispute resolution", Leadership \& Organization Development Journal, Vol. 26 Issue: 4, pp.263-279, https://eresources.mku.ac.ke:2079/10.1108/01437730510600643

Gabčanová, I. (2011). "The employess - the most important asset in the organizations", Human Resources Management \& Ergonomics, v, 1-12. https://doi.org/10.1111/b.9780631234104.2002.00012.x

Global Nonviolent Action Data Base (2011). "Rwanda textile workers strike against unfair labour practices, 2011". Retrieved on 20 ${ }^{\text {th }}$ August 2019 from https://nvdatabase.swarthmore.edu/content/rwandan-textileworkers-strike-against-unfair-labor-practices-2011

Harry Matlay, (1999) "Employee relations in small firms: A micro-business perspective", Employee Relations, Vol. 21 Issue: 3, pp.285-295, https://eresources.mku.ac.ke:2079/10.1108/01425459910273125

ILO

Statistics. https://www.ilo.org/ilostat/faces/oracle/webcenter/portalapp/pagehierarchy/Page21.jspx;ILOSTATCOOKIE $=$ xs03Ukd65DAnytMXB6TlozzDFnUTkwmf9ztncr_bXekohhs3KhvQ!774218261?_afrLoop=3206602284 201066\& afrWindowMode $=0 \&$ afrWindowId $=$ null $\# ! \% 40 \% 40 \% 3 \mathrm{~F}$ afrWindowId $\% 3$ Dnull $\% 26$ afrLoop $\%$ 3D3206602284201066\%26 afrW $\bar{W}$ indowMode\%3D0\%26_adf.ctrl-state\%3D15wn2kywnm_4

Itika, J. S. (2011). Fundamentals of Human Resource Management. Emerging Experiences from Africa. Leiden: African Studies Center, University of Groningen/Mzumbe University

Jie Shen, (2008) "The characteristics and historical development of labour disputes in China", Journal of

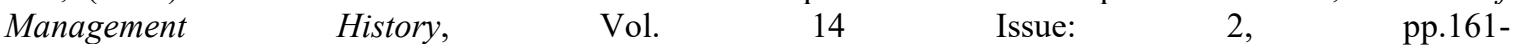
173,https://eresources.mku.ac.ke:2079/10.1108/17511340810860276

Labour Law No. 66/2018 of 30/08/2018 Law Regulating Labour in Rwanda. Official Gazette no. Special of $06 / 09 / 2018$

Maree, Johann (2016). "From a Culture of Silence to a Culture of Insurgence: Black Employee Voice in South Africa over Half a Century", Employee Voice in Emerging Economies. 2016, 137-192.

Nantege, M.(2017). "Effects of employee relations on teachers' performance in government aided primary schools in Wakiso District, Uganda", Retrieved from http://makir.mak.ac.ug/handle/10570/5735

Nikoloski, K., Dimitrova, J., Koleva, B., \& Kacarski, E. M. (2014). "From Industrial Relations to Employment Relations with Focus on Employee Relations", International Journal of Sciences: Basic and Applied Research, 18(2), 117-124. Retrieved from http://eprints.ugd.edu.mk/11569/1/3096-7295-2-PB.pdf 
Omotayo, O. A. \& Ome-Ogeonu, A. (2014). "Dunlopian Industrial-Relations System. A Myth or Heuristic Device?" Research on Humanities and Social Sciences. Vol.4, No.25, 2014. Retrieved on 22nd August 2019 from https://pdfs.semanticscholar.org/d4a2/47d87744c5773606759f2c14136c522fb2a3.pdf

Saji K. Mathew, Robert Jones, (2012). "Satyagraha and employee relations: Lessons from a multinational automobile transplant in India", Employee Relations, Vol. 34Issue: 5, pp.501-517, https://eresources.mku.ac.ke:2079/10.1108/01425451211248550

The Constitution of the Republic of Rwanda of 2003 Revised in 2015. Official Gazette $n^{\circ}$ Special of 24/12/2015

Wilkie, D. (2018). “Are Managers Friendly? Should they be?” SHRM. Retrieved on $19^{\text {th }}$ November 2018 from www.shrm.org.

World Economic Forum, Executive Opinion Survey 2017).Retrieved on $19^{\text {th }}$ November 2018 from http://www3.weforum.org/docs/GCR2017-

2018/05FullReport/TheGlobalCompetitivenessReport2017\%E2\%80\%932018.pdf 